\title{
Establishment and Practice of Spatial Planning Method of New Cities Ecological Security Pattern — Take Longtan New City of Nanjing for Example
}

\author{
Caixia Kang, Qing Lu, Qian Zhao, Zhiheng Zhang, and Huihui Nan
}

\begin{abstract}
With the rapid expansion of urbanization, urban construction has produced a series of significant impacts on the original ecological and natural environment, including water environment pollution, biological habitat loss and atmospheric environment pollution, thus causing urban problems like rain, flood and haze events. As an important growth pole in urbanization, new cities is often at the edge of city and the area where urban and rural areas meet. It is the most ecological sensitive area in construction and the weakest in planning and management, which is of great significance for the sustainable development of ecological environment. At present, the ecological planning mainly focuses on large river basins and lacks research and practice based on the premise of new city development. How to establish a set of ecological planning methods suitable for the development and construction of new cities is of great significance in the current urban development and construction. By constructing the spatial planning method of ecological security pattern at the scale of the new city, this paper puts forward a complete technical route method that is suitable for the new city system from planning to construction evaluation, and applies this method in the new cities of Longtan, Nanjing. This study aims to actively guide the ecological protection and utilization in the construction of China's new cities at the current stage, rather than simply passive protection. Through the construction of ecological security pattern, it fills in the blank of the research on the large-scale ecological systematic planning and construction of new cities, which is of great significance for the sustainable development of China's current ecological civilization.
\end{abstract}

Index Terms-Ecological security pattern, sustainable development of new city, ecological planning.

\section{INTRODUCTION}

Global warming and rapid urbanization are seriously affecting urban living environment, ecosystem services and human well-being. Urbanization leads to the natural, half natural ecosystem to artificial ecosystem, will seriously affect the ecological system structure, the process (including water, heat and other processes) and the service function (including support, supply, adjust and culture), leading to the urban heat island and the extreme events, frequent rain flood damage, atmospheric environment worsening pollution and other

Manuscript received September 14, 2018; revised December 6, 2018 This work was supported in part by the Urban Space Planning and Architectural Design co., LTD., Beijing. Urban Space Planning and Architectural Design co., LTD. company has won "Top 10 Institutes of Big Data Application in Urban Planning Industry" in 2018.

The authors are with the Research Center Department of Urban Space Planning and Architectural Design co., LTD., Beijing, 100001, China (e-mail: kcx1024@163.com, vluqing@cfldcn.com, zhaoqian0922@foxmail.com, thezhangzhiheng@126.com, vnanhuihui @cfldcn.com). issues [1].

Since the reform and opening up, China's cities and towns have been expanding rapidly. According to the national bureau of statistics, from 1978 to 2015, China's urbanization rate increased from 18 percent to about 57 percent. It is expected to reach 60 percent in 2020 and 70 percent in 2030 [2]. The rapid increase of new urban areas in China reflects the acceleration of China's urbanization process on the one hand, and also exposes the phenomenon of blind expansion and unreasonable development in urban construction on the other hand. How to reasonably guide the development of new urban areas and avoid the excessive destruction of ecological environment has become an important issue facing China's new urban construction at present.

\section{IMPACTS OF URBANIZATION ON THE NEW CITY'S ECOLOGICAL ENVIRONMENT}

New city bases are often located on the edge of urban and rural areas, with abundant natural landforms and ecological resources and huge potential of original resources. New city is an ecologically sensitive region, and forms an attachment relationship between long-term development and main urban areas [3]. Relevant scholars believe that the urban-rural junction is the most active and complex region of land use, which is of great significance for its rational development and construction for the sustainable development of society, economy and ecological environment [4]. The ecological function of the urban fringe area is increasingly prominent. The transformation from "binding belt" to "protective layer" is not only a very important ecological service production place for the city, but also a buffer zone for the city to cope with ecological risks [5].

According to international experience, in ecologically sensitive regions, simple and passive protection is not the best way to protect nature and species when faced with economic development challenges, but may accelerate the degradation. The coordination of production, living and ecology is the best plan [6].

\section{Research Status of Ecological Planning of New CITIES IN DOMESTIC AND ABROAD}

Many attempts have been made in domestic and abroad to control the blind spread of urban fringe areas. So far, most of the work is to guide the extension trend of the city and regulate the development mode of the city, hoping that the future shape of the city meets the expectations of human 
beings. From e.h. oward's "garden city" in 1899 to Britain's "satellite city construction," as well as the American idea of "compact cities" and "smart growth."

For China, how to learn from and summarize the successful experience and lessons in domestic and abroad and choose the development mode of regional ecological construction suitable for its national conditions has become an important issue to be considered in the development of new cities at present. Domestic researchers mainly focus on urban fringe areas through the control of urban and rural land planning. For example, shengming (2010) evaluated the implementation effect of basic ecological control area in shenzhen in five years. Yu kongjian systematically constructed a method system from a single ecological process to a landscape security pattern based on the study of landscape ecological security pattern. However, this method was rarely used systematically in the scale of the new city and did not simulate the evolution of the ecological pattern after the development of the new city.

It is of great significance to formulate the operating system of the protective utilization plan of the basic ecological control area at the new city scale, to adopt dynamic and active protection ideas, and promote the ecological protection and development of the new city.

\section{The Ecological Problems Faced by NeW City CONSTRUCTION AND THE RESEARCH OBJECTIVES OF THIS PAPER}

The rapid construction of unorganized new cities will lead to many negative ecological effects, including soil pollution, groundwater reduction, surface water pollution, air pollution, wetland degradation and biological habitat reduction. At the same time, it will lead to a series of urban disasters, such as frequent urban floods, debris flows, massive disappearance of natural resources, animal deaths caused by Marine garbage, persistent greenhouse effect and frequent occurrence of extreme weather disasters. How to plan ahead and systematically avoid these problems in new city construction is the core goal of new city ecological construction. The most scientific way to avoid ecological disasters in advance is not to make up for them after they happen. This is also the core purpose and significance of this paper.

\section{Establish the Spatial Planning Method of the NEW CITY'S ECOLOGICAL SECURITY PATTERN}

As a relatively independent ecological unit, new city should build a complete ecological planning and protection system. Based on miss yu kongjian's "anti-planning" theory, this study constructed a technical research system applicable to the scale of the new city from a single process to a comprehensive ecological security pattern, and carried out practical application of this method system in Nanjing Longtan new city, which played an important role in guiding the ecological construction of Longtan new city.

\section{A. Establishment of a Single Process System Method}

Through the single process of identifying various natural elements in the background of the new city, including hydrological process, geological disaster process, biological vertical and horizontal process, cultural heritage experience process, recreation experience process and urban wind and thermal environment analysis, the single ecological security pattern is identified and designed according to the dynamic and trend of the single ecological process. These single ecological security patterns have established systematic ecological infrastructure and potential ecological infrastructure of the new city, and the integrated ecological security pattern formed by the combination of single ecological security pattern has realized and guaranteed the sustainable ecosystem services of the new city.

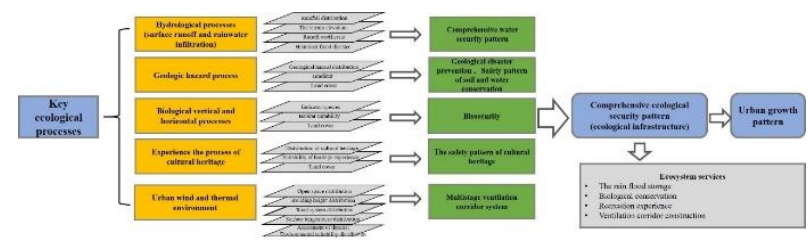

Fig. 1. Method and technical route of new city ecological security pattern.

\section{B. Framework of Ecological Comprehensive Security Pattern}

Ecological security pattern is a way to identify and build ecological infrastructure. Corridor is the main structure of ecological infrastructure. Ecological infrastructure as a basic landscape pattern to improve and guarantee the function of ecological services [7].

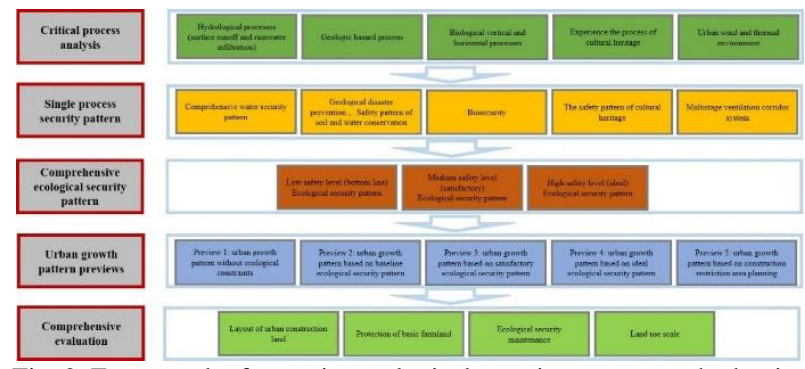

Fig. 2. Framework of new city ecological security pattern method units.

\section{Ecological PlanNing Practice of Longtan NeW CITY}

\section{A. Overview of Longtan New City}

Longtan new city is located at the east gate of Nanjing, adjacent to the Yangtze river, next to Qixia mountain in the west and Baohua mountain in the south. It is about 35 kilometers away from the downtown of Nanjing, belonging to the edge of the city. It is a special area at the junction of Nanjing, Zhenjiang and Yangzhou, presenting a landscape pattern of "piang river belt river, and mountains and rivers are mutually dependent". Most of the land in the new city is still under development, but some ecological and environmental problems have already appeared. It is mainly reflected in water pollution, lack of waterfront buffer zone in river course, and insufficient ecological benefits. The riverfront is occupied seriously by construction land; Mining in Qinglong mountain caused serious damage, significant soil and water loss problems; The air quality is poor, and serious harm to human health is achieved in winter.

\section{B. Ecological Sustainability Protection Strategy of}




\section{Longtan Based on Development}

With the development process, Longtan new city is about to face the impact of intensive development on ecological pattern and environment. In order to actively solve some problems existing in the current situation and cope with the challenges after development, this study constructed water ecological security pattern, biological security pattern, urban thermal environment analysis, and conducted regional thermal environment simulation. It is predicted that the new city will face three aspects: the water surface rate will be significantly reduced after construction, the biological core habitat will be reduced, and the heat island effect of the new city will be highlighted after development.

1) Build an ecological security pattern of a single process

Through analyzing the single process pattern of water ecological security pattern, biological security pattern and wind thermal environment, this study finally constructed the comprehensive security pattern system of Longtan new city and put forward targeted strategies.

- Construction and protection of water ecological security pattern

In order to restore the natural hydrological process of Longtan new city and maintain the safety of urban rain flood, through ArcGIS spatial analysis technology, rain flood, surface runoff and other processes were analyzed and simulated. The safety pattern of rain flood for maintaining the safety of Longtan rain flood was identified, and the comprehensive water safety pattern was constructed by considering the protection of surface drinking water sources and the supply of groundwater.

To build a comprehensive water ecological security pattern and clarify the development requirements at different levels of high, medium and low security.

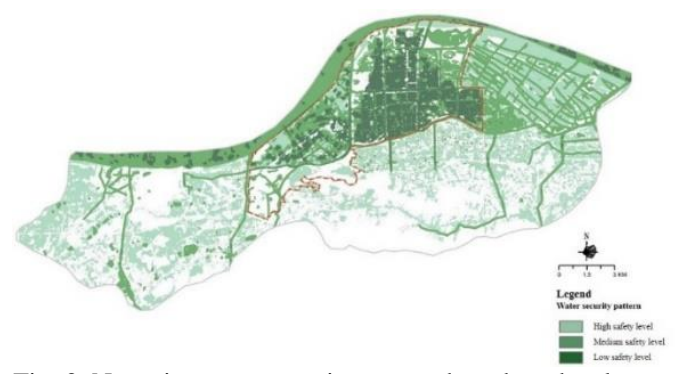

Fig. 3. New city water security pattern based on development.

Improve the river bend, make reasonable use of existing potholes and ponds, improve the water quality of small watershed and improve the water surface rate of the planned area. Establish low, medium and high buffer protection zones according to different waterfront functions.

Optimize the revetment space according to the classification, giving priority to natural revetment and taking into account the requirements of urban production. The new city is classified into four types: natural and ecological, natural landscape, urban production and urban life.

Include flexible development mode, and rationally use small water bodies for rain flood management according to different land types, such as residential land, commercial land, urban green land, urban square, etc.

- Construction and protection of biosecurity pattern Faced with the problems and challenges of serious habitat destruction and loss of biological core habitat in qinglong mountain, this study based on the selection and analysis of focus species in the new city, uses the minimum resistance model and GIS spatial analysis method to identify and plan key patterns of biodiversity conservation. Based on the construction of ecological security pattern, the solutions of preserving and core patches and constructing ecological strategic points and ecological corridor system are proposed.

TABLE I: WATERFRONT BUFFER REQUIREMENTS AND FUNCTIONS

\begin{tabular}{|c|c|c|c|c|c|}
\hline & $\begin{array}{c}\text { High } \\
\text { sensitiv } \\
\text { e(botto } \\
\text { m) }\end{array}$ & $\begin{array}{c}\text { The } \\
\text { sensitiv } \\
\text { e(suitab } \\
\text { le) }\end{array}$ & $\begin{array}{c}\text { Low } \\
\text { sensitivity } \\
\text { (best) }\end{array}$ & Major rivers & $\begin{array}{l}\text { Buffer } \\
\text { function }\end{array}$ \\
\hline $\begin{array}{l}\text { First stage } \\
\text { drainage }\end{array}$ & $0-60 \mathrm{~m}$ & $60-80 \mathrm{~m}$ & $80-150 m$ & $\begin{array}{l}\text { The Yangtze } \\
\text { River }\end{array}$ & $\begin{array}{l}\text { Purify } \\
\text { water, } \\
\text { protect } \\
\text { biodiver } \\
\text { sity and } \\
\text { regulate } \\
\text { air } \\
\text { temperat } \\
\text { ure }\end{array}$ \\
\hline $\begin{array}{l}\text { Secondary } \\
\text { drainage }\end{array}$ & $0-30 \mathrm{~m}$ & $30-0 \mathrm{~m}$ & $60-80 \mathrm{~m}$ & $\begin{array}{l}\text { Bianmin } \\
\text { river, } \\
\text { Qxiang } \\
\text { river, } \\
\text { Sanjiang } \\
\text { river }\end{array}$ & $\begin{array}{l}\text { Purifyin } \\
\text { g water }\end{array}$ \\
\hline $\begin{array}{c}\text { Tertiary } \\
\text { drainage } \\
\text { and below }\end{array}$ & $0-10 \mathrm{~m}$ & $10-30 \mathrm{~m}$ & $30-50 \mathrm{~m}$ & $\begin{array}{l}\text { Jingan river, } \\
\text { Yanzha } \\
\text { river, } \\
\text { Xuanzha } \\
\text { river, } \\
\text { Shuanggang } \\
\text { river, } \\
\text { Dongshan } \\
\text { river, etc }\end{array}$ & $\begin{array}{l}\text { Soil and } \\
\text { water } \\
\text { conserva } \\
\text { tion, } \\
\text { dust } \\
\text { adsorpti } \\
\text { on }\end{array}$ \\
\hline
\end{tabular}

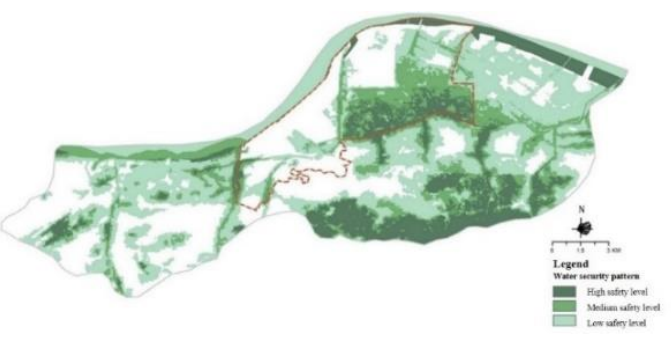

Fig. 4. New city biosecurity pattern based on development

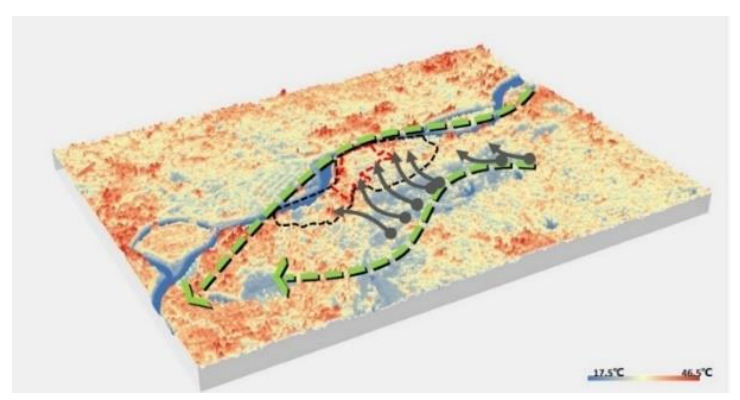

Fig. 5. Regional thermal environment simulation.

- Construction of ventilation corridors

Faced with the problems and challenges of poor air quality, low pollutant evacuation capacity, and prominent heat island 
effect of the new city, based on landsat8 image, this study used single-window method to invert surface temperature to obtain the distribution of temperature field of the new city of Longtan, and proposed the construction scheme of wind corridor.

Connect the wind source led by the east wind, construct the Yangtze river as the first-level wind corridors, Jingan river and Bianmin river as the second level wind corridors.

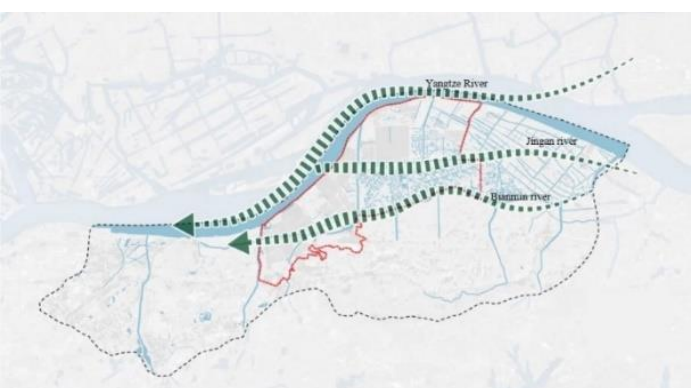

Fig. 6. Suggestions for the construction of the first-level and second-level wind corridors.

The fresh air sources of Baohua mountain and the Yangtze river were used to build the three-level wind corridors of Shuanggang river, Yanzha river, Xuanzha river, Sanjiang river and Qixiang river.

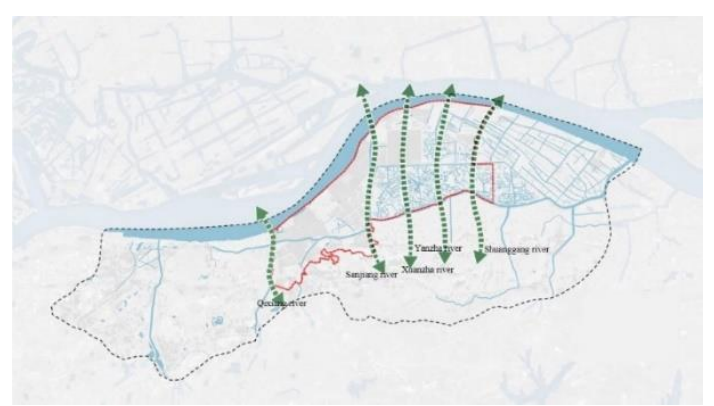

Fig. 7. Suggestions for the construction of three-level wind corridors.

2) Construction of comprehensive ecological security pattern

The combination of single process analysis of water security pattern, biological security pattern and ventilation corridor construction plan to establish the comprehensive ecological security pattern of Longtan new city. Based on the analysis of the structure, the development and construction strategy is proposed to establish the ecological comprehensive security pattern system with six patches and four nodes in nine corridors. The combination of protection and utilization provides scientific strategic support for ecological protection and sustainable development in new city construction.

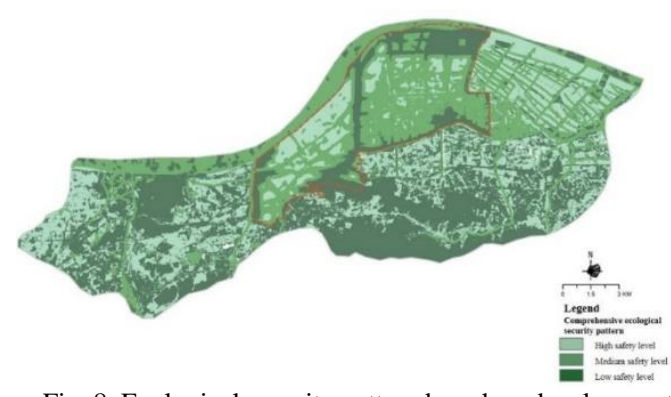

Fig. 8. Ecological security pattern based on development.

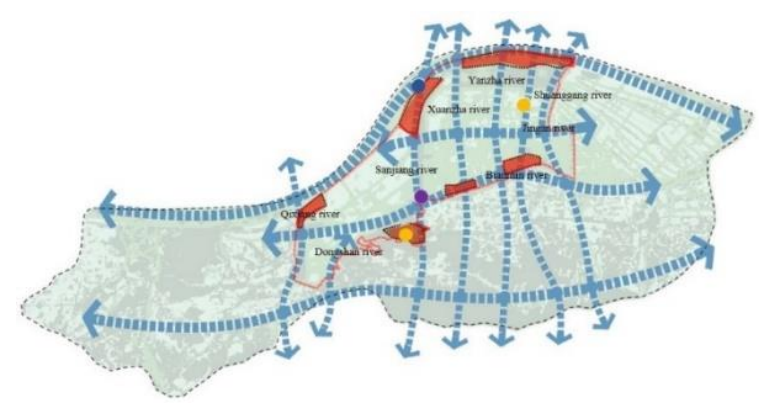

Fig. 9. Strategy of nine corridors six patches four node.

Through the construction of the comprehensive ecological security pattern, the new city is divided into four ecological units: ecological control area, ecological optimization area, ecological construction area and ecological restoration area, providing different ecological protection development strategies for different types of units.

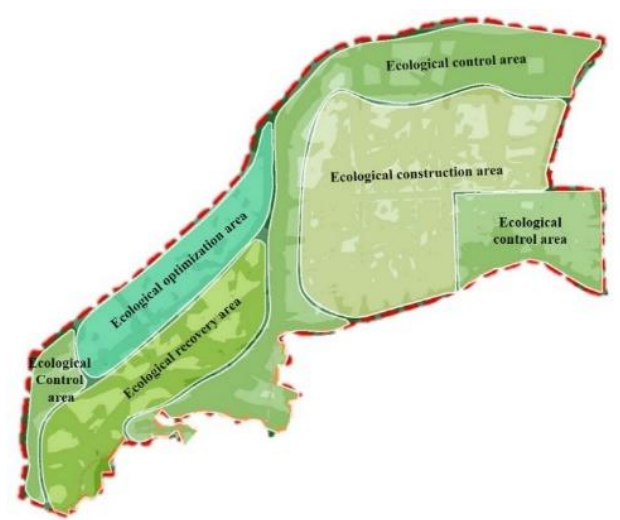

Fig. 10. New city ecological zoning based on development.

The protection of ecological control area focuses on wetland restoration and mountain forest habitat protection; Ecological recovery area focuses on controlling rainwater runoff and industrial pollution; Ecological optimization area focuses on strengthening the construction of ecological infrastructure; Ecological construction area focuses on protecting the ecological background, improving the quality of landscape.

TABLE II: INDEX REQUIREMENTS OF NEW CITY ECOLOGICAL ZONING

\begin{tabular}{|c|c|c|c|c|}
\hline \multicolumn{5}{|c|}{ CONTROL } \\
\hline \multirow[b]{2}{*}{$\begin{array}{c}\text { Recent } \\
\text { indicators }\end{array}$} & \multicolumn{2}{|c|}{$\begin{array}{l}\text { Mandatory } \\
\text { index }\end{array}$} & \multicolumn{2}{|r|}{ Guide indicator } \\
\hline & $\begin{array}{l}\text { The } \\
\text { rate }\end{array}$ & $\begin{array}{c}\text { The } \\
\text { water } \\
\text { rate }\end{array}$ & $\begin{array}{c}\text { The } \\
\text { intensity of } \\
\text { the } \\
\text { developme } \\
\text { nt }\end{array}$ & Building height \\
\hline Ecologica & & & Prohibit & \\
\hline $\begin{array}{l}1 \text { control } \\
\text { area }\end{array}$ & $60 \%$ & $8 \%$ & $\begin{array}{l}\text { polluting } \\
\text { enterprises }\end{array}$ & \\
\hline $\begin{array}{c}\text { Ecologica } \\
1 \\
\text { constructi } \\
\text { on }\end{array}$ & $45 \%$ & $6 \%$ & $\begin{array}{l}\text { Medium - } \\
\text { medium } \\
\text { high }\end{array}$ & \\
\hline $\begin{array}{c}\text { on area } \\
\text { Ecologica }\end{array}$ & & & strength & $\begin{array}{l}\text { The height of the main wind } \\
\text { corridors adjacent to the }\end{array}$ \\
\hline $\begin{array}{c}1 \\
\text { optimizati } \\
\text { on area }\end{array}$ & $30 \%$ & $4 \%$ & $\begin{array}{l}\text { Low } \\
\text { intensity }\end{array}$ & $\begin{array}{c}\text { row building is less than } 40 \\
\text { meters }\end{array}$ \\
\hline $\begin{array}{c}\text { Ecologica } \\
1 \text { recovery } \\
\text { area }\end{array}$ & $35 \%$ & $6 \%$ & $\begin{array}{l}\text { Low } \\
\text { intensity }\end{array}$ & \\
\hline $\begin{array}{c}\text { Block } \\
\text { plan }\end{array}$ & $40 \%$ & $7 \%$ & -- & \\
\hline
\end{tabular}




\section{CONCLUSION}

In this study, an ecological planning technology system applicable to the sustainable development of new cities in China has been constructed. Through the single process analysis and the construction of comprehensive ecological security pattern, the new city can achieve the objectives of protection and development in the best way, satisfy the spatial needs of different land usea, and build a smart development pattern model of the new city.

This study fills the blank of research on eco-systematic protection planning and utilization of China's new city development based on the development premise. It puts forward new planning and practice directions for ecological civilization construction and sustainable development of new city under the current background of urbanization, which is of strategic significance.

However, the eco-background of different new citys has its own characteristics. In the specific research practice, it is suggested to analyze and study according to the characteristics of different new cities.

\section{ACKNOWLEDGMENT}

Caixia Kang Author thanks to President Zhen Cai for his guidance and the hard work of the project team members.

\section{ANNOTATION}

Part of the data in this paper is from the land use statistics of the overall planning of Longtan new city

\section{REFERENCES}

[1] W. H. Kuang, T. R. Yang, and F. Q. Yan, "Regional surface background characteristics and ecological control of Xiongan new area in hebei [J]," Journal of Geography, 2017, vol. 72, no. 6, pp. 947-959.

[2] Q. L. Luo et al., "Research on protective utilization planning path of urban basic ecological control areas [M]," Beijing: Science Press, 2016.

[3] L. Li, "Stitching" strategy in the compact eco-city planning - An analysis of the planning and design of guiyang huayuan town," Planner, 2011 , vol. 27 , no. 5 , pp. $56-62+68$.

[4] R. Xie, "Land use and sustainable development in urban and rural areas," National Economy, 1998, no. 5, pp. 27-28.

[5] M. L. Qin, J. Zhao, J. Ya et al., Planning Theory and Method of Low-Carbon Urban FRINGE areas, Beijing: China Building Industry Press, 2017.

[6] J. Q. Zhou, L. Q. Xu, and B. T. He, "Study on the development of new cities in ecologically sensitive areas based on flexible thinking -- taking wuhan huashan eco-new city as an example," Journal of Urban Planning, 2014, no. 6, pp. 77-84.

[7] K. J. Yu et al., Anti-planning Approach, Beijing: China Building Industry Press, 2005.

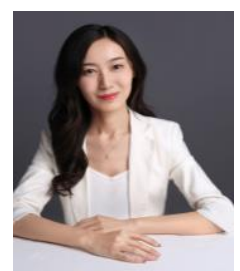

Caixia Kang was born in 1985, Ningxia China. She is senior researcher in the research center department of Urban Space Planning and Architectural Design co., LTD. (Beijing). She got the master degree of environmental science in Jilin University, 2009. Her major field is ecosystem engineering and digital management, ecological planning and Sponge city planning. She worked in the School of Environment of Tsinghua University, Beijing Tsinghua Tongheng Planning and Design Research Institute, Tsinghua University Engineer Title.

In recent 10 years work experience, be responsible for and participate in a number of research projects, including the national 863 major method of international cooperation in scientific research, sino-australian international cooperation research, national urban pilot declare sponge and special planning study (Zhuhai, Qianan, Pingxiang, Fuzhou, Zhenjiang, Qingdao), national wetland park construction concept planning and feasibility study, long-term watershed comprehensive management of Dianchi Lake, etc.

During my work, I completed the project and won the second prize of Jiangsu provincial survey and design; International Federation of Landscape Architects (IFLA,2018) award for basic contribution of rain flood management and ecological diversity; Published 5 core journal papers; Jointly apply for 3 software Copyrights.

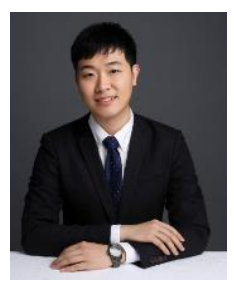

Qing Lu was born on 1986, Hebei, China. He is principal researcher in the Research Center Department of Urban Space Planning and Architectural Design co., LTD. (Beijing). He got the master degree of Urban Engineering at the Tokyo University, Japan, 2013. His major field is urban ecology, metropolitan area and smart city.

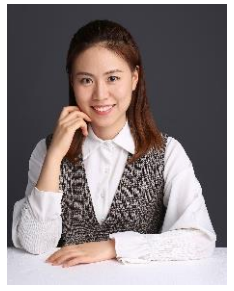

Qian Zhao was born in 1992, Chongqing, China. She is researcher in the Research Center Department of Urban Space Planning and Architectural Design co. LTD. (Beijing). She got the master degree of urban and rural planning at Renmin University, China, 2015. Her major field is region planning and sustainable development.

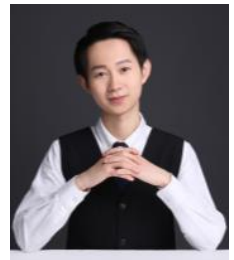

Zhiheng Zhang was born in 1991, Shanxi, China. He is researcher in the Research Center Department of Urban Space Planning and Architectural Design co., LTD. (Beijing). He got the master degree of Geography at Lanzhou University, China, 2016. His major field is urban computing and regional development.

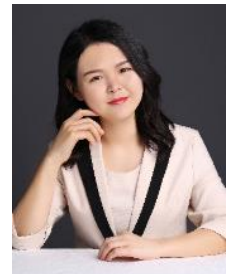

Huihui Nan was born in 1993, Henan, China. She is research assistant in the Research Center Department of Urban Space Planning and Architectural Design co., LTD. (Beijing). She got the master degrees of urban and regional planning and transportation engineering at University of Florida, Gainesville, FL, USA, 2017. Her major field is sustainable development and transportation safety. 